\title{
OPTIMIZATION OF SELECTIVE-TYPE AFTERTREATMENT SYSTEMS IN DIESEL ENGINES
}

\author{
Álvaro Augusto de Mattos Lourenço ${ }^{1}$, Fábio Luz Almeida ${ }^{1}$, Leandro Seizo Glovaski ${ }^{1}$ \\ ${ }^{1}$ MWM Motores Diesel \\ E-mails: alvaro.lourenco@navistar.com.br, fabio.almeida@ navistar.com.br, \\ leandro.glovaski@navistar.com.br
}

\begin{abstract}
Diesel engine technology has been driven by stringent regulation. To fulfill this demands emission control systems are constantly improving. In this context exhaust gas aftertreatment development assumes an important role however the in-cylinder emissions control is fundamental to comply with future legislations.
\end{abstract}

Among the aftertreatment systems applied to reduce diesel engines combustion products the Selective Catalytic Reduction (SCR), which converts nitrogen oxides, $\left(\mathrm{NO}_{\mathrm{x}}\right)$ into nitrogen $\mathrm{N}_{2}$ and water $\mathrm{H}_{2} \mathrm{O}$ via dosing a chemical reducing agent containing ammonia in the exhaust system is an already proven solution for most medium and heavy duty Diesel (MDD and HDD) applications.

The current work aims to compare the behavior of different urea and formamide-based reducing agents using a selective catalytic reduction aftertreatment system (ATS) when it comes to $\mathrm{NO}_{\mathrm{x}}$ reduction. Another purpose of this study in addition to studying the $\mathrm{NO}_{\mathrm{x}}$ reduction is also to understand the effects or side-effects in other gases like carbon monoxide (CO), carbon dioxide $\left(\mathrm{CO}_{2}\right)$, hydrocarbon $(\mathrm{HC})$, oxygen $\left(\mathrm{O}_{2}\right)$, ammonia $\left(\mathrm{NH}_{3}\right)$ and to discuss in detail the potential of using this alternative reducing agents to comply with EURO VI standards and optimized SCR systems towards increasing their efficiency.

Regarding the SCR catalyst system as to $\mathrm{NO}_{\mathrm{x}}$ reduction it is possible to say that urea-based mixtures are the most efficient ones but on the other hand are also those that present higher values of ammonia slip. The formamide-based mixtures do not present efficiency as significant as the urea-based mixtures but the ammonia slip levels produced by those mixtures are virtually none.

With regard to $\mathrm{CO}$ and $\mathrm{HC}$ emissions the formamide-based mixtures have presented significant increase on the emissions of those two gases while in the urea-based mixtures the values have remained virtually unchanged.

\section{INTRODUCTION}

Air quality present in large cities has been a major concern in the last decades and has major impact on the heath of people [1]. Generically the sources of pollution can be divided into stationary and mobile. Stationary include emissions from factory chimneys, crude oil burning in industries, household incinerators, among others; while mobile includes several means of transportation, including trucks, buses and cars. 
The most important species of pollutants emitted by combustion sources, stationary or mobile are monoxide carbon, organic compounds (unburned hydrocarbons or only partially burned), sulfur oxides, particulate matter $(\mathrm{PM})$ and $\mathrm{NO}_{\mathrm{x}}$.

Government agencies worldwide have acted as public control agents in order to impose the air pollution reduction [2]. The world has been governed by five major legislative standards:

- $\quad$ Environmental Protection Agency (EPA).

- $\quad$ California Air Resources Board (CARB).

- $\quad$ European Commission (EURO).

- $\quad$ Vehicle Certification Agency (VCA) from United Kingdom (UK).

- $\quad$ Japanese Ministry of Land, Infrastructure and Transportation (JMLIT).

Those agencies are constantly forcing engine and vehicle manufacturers to look for technological solutions that can reduce the emissions levels. As shown in Figure 1 in Europe $\mathrm{NO}_{\mathrm{x}}$ and PM have been reduced up to $95 \%$ and $97 \%$ respectively from 1992 to 2013 when EUVI standards were implemented.

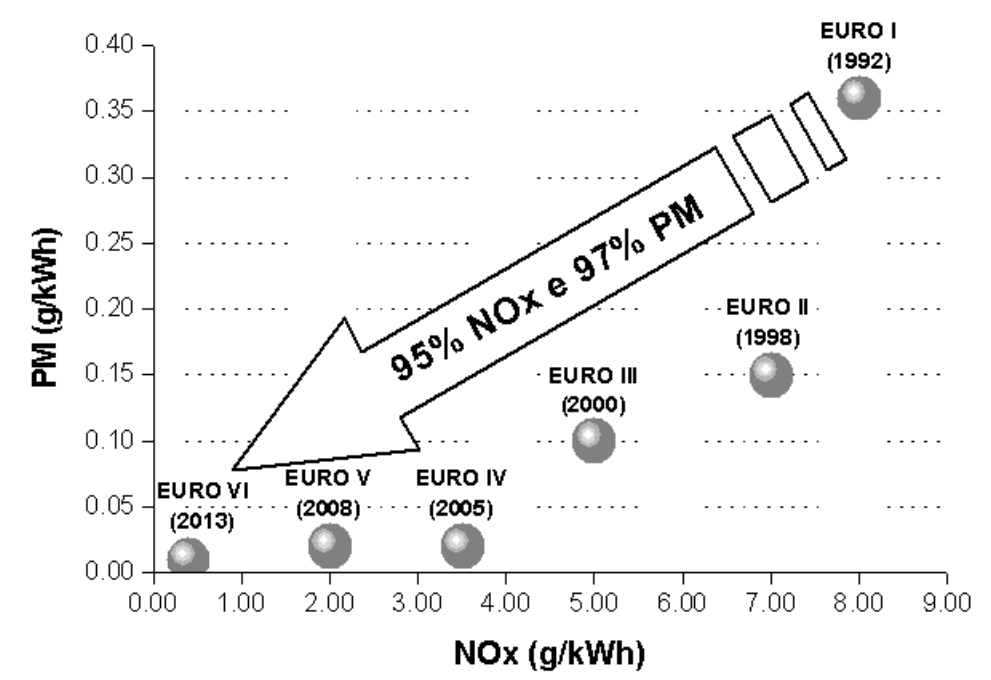

Figure 1: $\mathrm{NO}_{\mathrm{x}}$ and Particulate Matter reduction in Europe over the years.

In Brazil the regulatory agency is national council that regulates industrial impact on environment (CONAMA) and established PROCONVE standards based on EURO standards.

Diesel engine emissions can be controlled by applying different technologies in two different moments. The first one can be done during the combustion process via in-cylinder strategies such as fuel injections with increasingly higher injection pressures, high pressures originating from turbochargers, exhaust gases recirculation (EGR), start of injection (SOI) changes among others or via exhaust gases aftertreatment where different technologies can be applied. Depending on the legislation stringency most of the engine manufacturers have to work not merely on the in-cylinder side in order to reach the tighter emissions levels demands but also on suitable advanced ATS.

Advanced aftertreatment systems include Diesel Oxidation Catalyst (DOC), Selective Catalytic Reduction (SCR), Lean $\mathrm{NO}_{\mathrm{x}}$ Trap (LTN) and Diesel Particulate Filters (DPF). These and others technologies have been widely used to reduce $\mathrm{NO}_{\mathrm{x}}, \mathrm{PM}, \mathrm{HC}$ and $\mathrm{CO}$ emissions. 
DOC promotes the chemical oxidation of $\mathrm{CO}, \mathrm{HC}$, as well as the soluble organic fraction from PM. It also oxidizes sulfur dioxide $\left(\mathrm{SO}_{2}\right)$ present in exhaust emissions due to the presence of sulfur in fuels. Hydrocarbon-based ATS the LNT are the preferred solution for passenger cars and uses diesel fuel as reducing agent instead of ammonia as on the regular SCR systems. In the Lean $\mathrm{NO}_{\mathrm{x}}$ Traps catalyst $\mathrm{HC}$ reacts with $\mathrm{NO}_{\mathrm{x}}$ to form nitrogen $(\mathrm{N})$, carbon dioxide $\left(\mathrm{CO}_{2}\right)$ and water.

Among all available technologies SCR is recognized worldwide as the most effective $\mathrm{NO}_{\mathrm{x}}$ control technology for MDD and HDD applications. SCR catalyst systems are based on vanadium oxide or zeolites and have different operating temperatures and must be carefully selected for different applications. Details of the interaction of NO with different catalyst surfaces in the presence of various reducing agents or with direct decomposition of NO was described in [3]. SCR systems use a chemical reducing agent based on ammonia and it reduces the nitric oxide $(\mathrm{NO})$ or nitrogen dioxide $\left(\mathrm{NO}_{2}\right)$ through the oxidation process in the presence of oxygen. Nowadays the common and commercial ammonia source consist of a solution comprising 32\% urea (mass-based) and water commercially named AdBlue ${ }^{\circledR}$ in Europe and Diesel Exhaust Fluid (DEF) in North America. AdBlue ${ }^{\circledR}$ or DEF is introduced into the exhaust pipe after the turbocharger and converts to isocyanic acid and then to ammonia in the exhaust stream and reacts with $\mathrm{NO}_{\mathrm{x}}$ over a catalyst to form harmless nitrogen gas and water [4].

Although there are different possibilities of reducing agents as ammonia precursors the only commercial ammonia source used is $32 \%$ urea mass-based. In fact worldwide manufacturers have already decided to use the SCR systems with urea as a source of $\mathrm{NH}_{3}$. However that fact does not discard research mainly with experimental tests using alternative sources of $\mathrm{NH}_{3}$. Alternative routes are always welcome in any area of knowledge and experimental tests especially in critical areas such as energy and pollutants treatment. New stringent limits and all the issues regarding reducing agents availability in the market open new perspectives of research.

In the present paper the main idea is to know experimentally the behavior of some others sources of ammonia on a SCR system and all results observed were compared to urea-based solution (baseline). However the urea-based solution was previously compared to AdBlue ${ }^{\circledR}$ to guarantee a reliable baseline.

The experiments have been done using as reducing agents the following compounds:

- $\quad$ Adblue $^{\circledR}$ (mixture currently used in the automotive industry).

- $\quad$ Urea P.A. (aqueous mixture with $32 \%$ pure urea).

- $\quad$ Formamide P.A. (aqueous mixture with 35\% pure formamide).

Experimental tests in present work have been carried out on the European Stationary Cycle (ESC) as [5]. The ESC test cycle has been introduced together with the European Transient Cycle (ETC) and the European Load Response (ELR) tests for HDD engines emission certification as [5]. 


\section{SELECTIVE CATALYTIC REDUCTION (SCR)}

The $\mathrm{NO}_{\mathrm{x}}$ produced during the combustion process depends on numerous factors such as fuel composition, operation mode, combustion chamber design, among other factors. Each factor plays an important role on the final $\mathrm{NO}_{\mathrm{x}}$ produced. Some control techniques take advantage of the kinetic mechanism of $\mathrm{NO}_{\mathrm{x}}$ in contact with agents acting in different ways leading to reduction or complete annulment of $\mathrm{NO}_{\mathrm{x}}$. Among these techniques is the Selective Catalytic Reduction (SCR) as already mentioned.

$\mathrm{NO}_{\mathrm{x}}$ Selective Catalytic Reduction through nitrogen containing compounds as ammonia and urea, commonly known as SCR, has been developed and proven in stationary industrial applications [2]. SCR technology was first applied in thermal power generation in Japan around 1970, also followed by applications in thermal power plants used in Europe since the mid-1980s. In the United States the SCR systems have been introduced to gas turbines in the 1990s presenting a huge potential for $\mathrm{NO}_{\mathrm{x}}$ control in thermal power plants using coal as a source of power generation. In addition to coal and gas turbines, SCR applications also include facilities in refineries, heaters and boilers in the chemical industry and ovens and waste incinerators. As [6], the list of fuels used in these applications includes industrial gases, natural gas, crude light or heavy oil and pulverized coal. $\mathrm{NH}_{3}-\mathrm{SCR}$ technology applied to HDD vehicles has been developed to the commercialization stage and has been an option in series production of European truck manufacturing since 2001 [6].

In the selective catalytic reduction process $\mathrm{NO}_{\mathrm{x}}$ reacts with ammonia which is injected before the catalyst in the exhaust gases from the combustion in diesel engines. $\mathrm{NO}_{\mathrm{x}}$ in fact are selectively reduced by $\mathrm{NH}_{3}$ in the presence of a large excess of oxygen over various catalysts. Different catalytic systems based on vanadium oxide or zeolites have different operating ranges as a function of temperature and must be carefully selected [7]. The catalyst temperature greatly affects its conversion efficiency, which decreases at lower temperatures, but it also strongly depends on the catalyst material and catalyst design [7, 8 and 9]. Therefore urea dosage should be reduced as there is a risk of injected urea be not pulverized accordingly and convert into solid urea deposits. CFD simulations can assist failure-free design proposals [10] and optimized SCR systems [25]. Ammonia has been used for years in industrial processes, stationary diesel engines and marine engines as well. A series of chemical reactions that occur in the SCR system uses ammonia as a reducing agent, according to equations 1 to 4 described below. Several studies have been done on the ammonia mechanism under different conditions [11]. All these processes represent desirable reactions which reduce $\mathrm{NO}_{\mathrm{x}}$ to $\mathrm{N}_{2}$. Equation 1 represents the main reaction mechanism. Reactions given by Equations 3 through 4 involve the $\mathrm{NO}_{2}$ reagent. The $\mathrm{NH}_{3}-\mathrm{NO} / \mathrm{NO}_{2}$ reacting system described by Equation 4 is very fast. This reaction involves one more complex and less explored chemistry as compared to the $\mathrm{NH}_{3}-\mathrm{NO} / \mathrm{O}_{2}$ system.

The possible presence of a DOC upstream the SCR catalyst requires including also $\mathrm{NO}_{2}$ among the reactants in the kinetic model [12]. The major benefit of this solution is that in addition to the well known standard SCR reaction (Eq. 1) also the "Fast SCR" reaction (Eq. 4) occurs over the catalyst which grants a higher $\mathrm{NO}_{\mathrm{x}}$ reduction efficiency at low temperatures. Studies have been carried out on the reactivity of the full $\mathrm{NH}_{3}-\mathrm{NO} / \mathrm{NO}_{2}$ system by dynamic methods over a wide range of temperatures $\left(160<\mathrm{T}<425^{\circ} \mathrm{C}\right)$ and feed mixtures $\left(0 / 1<\mathrm{NO} / \mathrm{NO}_{2}<1 / 0\right)$, with the aim of identifying the main reactions prevailing in the different 
operating regions [13]. Notably, the greatest benefits from $\mathrm{NO}_{2}$ addition to the $\mathrm{NO} / \mathrm{NH}_{3}$ mixtures were evident in the low temperature range $\left(\mathrm{T}<250^{\circ} \mathrm{C}\right)$ where the activity of the standard SCR reaction (Eq. 1) is limited.

$$
\begin{aligned}
& 4 \mathrm{NH}_{3}+4 \mathrm{NO}+\mathrm{O}_{2} \rightarrow 4 \mathrm{~N}_{2}+6 \mathrm{H}_{2} \mathrm{O} \\
& 8 \mathrm{NH}_{3}+6 \mathrm{NO}_{2} \rightarrow 7 \mathrm{~N}_{2}+12 \mathrm{H}_{2} \mathrm{O} \\
& 4 \mathrm{NH}_{3}+2 \mathrm{NO}_{2}+\mathrm{O}_{2} \rightarrow 3 \mathrm{~N}_{2}+6 \mathrm{H}_{2} \mathrm{O} \\
& 2 \mathrm{NH}_{3}+\mathrm{NO}+\mathrm{NO}_{2} \rightarrow 2 \mathrm{~N}_{2}+3 \mathrm{H}_{2} \mathrm{O}
\end{aligned}
$$

There are also several undesired secondary reactions not listed here which can take place as a result of the catalyst nature, oxygen content, temperature or presence of acid gases. Figure 2 shows a typical ATS system applied to a HDD engine vehicle.

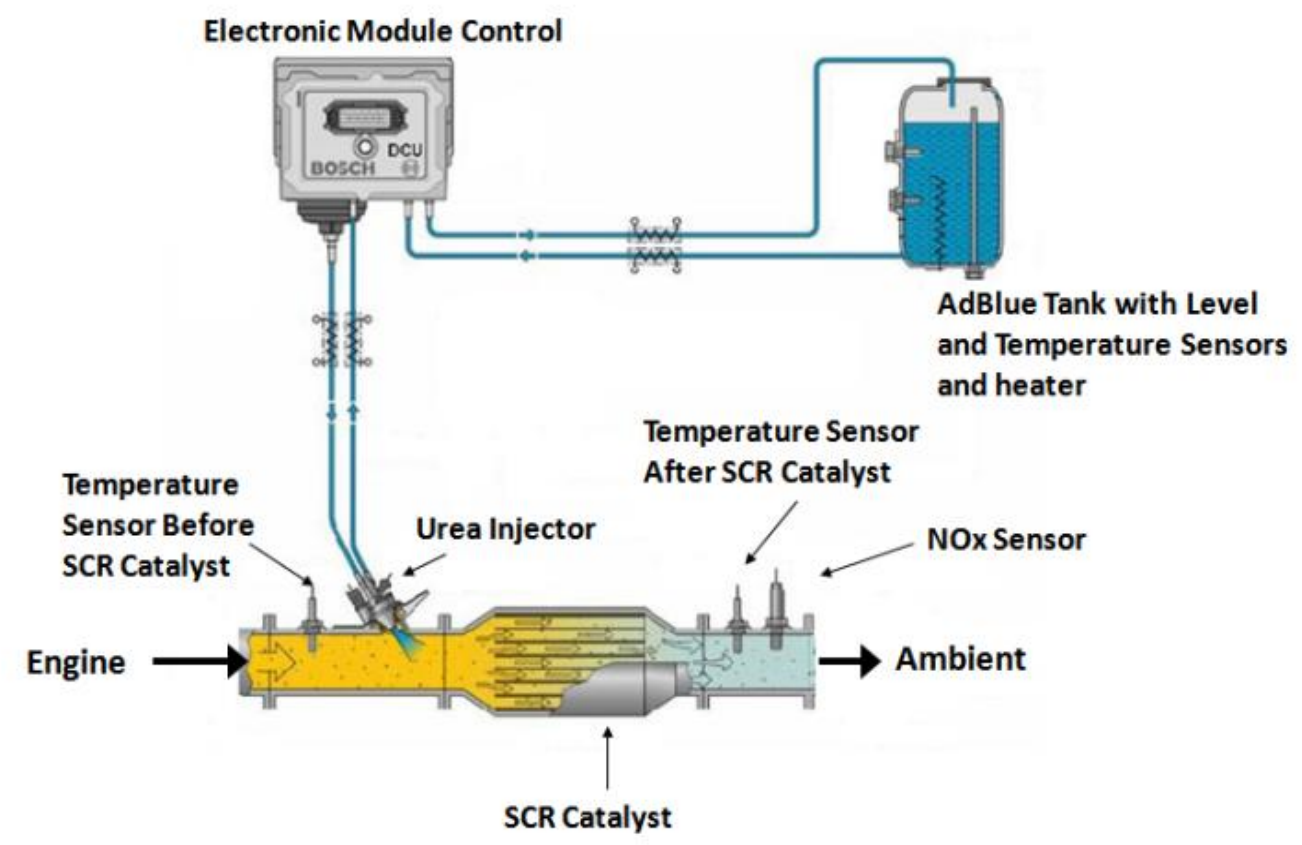

Figure 2: Vehicular system equipped with SCR aftertreatment system [14].

There are several authors who presented studies of implementation of SCR technique to diesel engine like [15] apud [2]. Different emphasis in studies concerns kinetics can be also found in the literature [16, 12 and 17]. Also some studies have been done with combination of systems $[18,19]$. Catalysts used in this study were capable of storing hydrocarbons to increase the conversion of $\mathrm{NO}_{\mathrm{x}}$ and to minimize the drawback in fuel consumption. With this system it is possible to simultaneously observe nearly $15 \%$ reduction in $\mathrm{NO}_{\mathrm{x}}$ emissions and about $25 \%$ in PM storing hydrocarbons released in the combustion of low temperature regimes and releasing them in conditions of high temperatures in order to reduce $\mathrm{NO}_{\mathrm{x}}$ emissions.

Some research lines did not employ ammonia as a reducing agent for $\mathrm{NO}_{\mathrm{x}}$ but rather studied the reduction using a selective catalyst and diesel itself as a reducing agent in an ATS for HDD vehicles [20]. It has been evaluated the potential of using plasma for reduction of $\mathrm{NO}_{\mathrm{x}}$ in an ATS of SCR-type in exhaust gases of a High Speed Diesel (HSD) engine at 
temperatures between 60 and $180^{\circ} \mathrm{C}$ [21]. Exhaust gases reduction system originating from a diesel engine applied to HDD vehicles has been assessed [2]. This system consisted of a DPF and a SCR assembly thus enabling a high conversion of the main products of combustion in diesel engines such as $\mathrm{NO}_{\mathrm{x}}, \mathrm{PM}, \mathrm{CO}$ and $\mathrm{HC}$. This system provides a reduction of up to $92 \%$ in $\mathrm{NO}_{\mathrm{x}}$ emissions along with a reduction of up to $70 \%$ in PM levels. Additionally a catalyst for ammonia slip control was used keeping the ammonia slip levels below $10 \mathrm{ppm}$ [22].

Other studies show that the urea dosing system control is important to reach desirable level of $\mathrm{NO}_{\mathrm{x}}$. Different control strategies involving urea dosing was presented, since the SCR process requires precise control of injection rate of ammonia [23]. An insufficient injection may result in low $\mathrm{NO}_{\mathrm{x}}$ conversions while relatively high injections can result in an undesirable release of ammonia to the atmosphere. This increases the $\mathrm{NH}_{3} / \mathrm{NOx}$ ratio.

Although SCR found great acceptance of application worldwide its usage in vehicle diesel engines also requires overcoming several problems. However this technology remains the only proven catalytic possibility capable of reducing $\mathrm{NO}_{\mathrm{x}}$ emissions to extremely low levels as required by future emission standards. In fact SCR technology has been chosen by several manufacturers of vehicles and engines as the technology to meet extremely low $\mathrm{NO}_{\mathrm{x}}$ legislation limits for HDD trucks and buses equipped with diesel engines such as EURO VI.

The $\mathrm{NH}_{3}$-SCR technology applied to HDD vehicles has been developed to the commercialization stage and has been an option in series production of European truck manufacturing since 2001 [2]. As in Europe most truck manufacturers in USA have decided for SCR aftertreament systems to meet new emissions limits mainly after stringent EPA 2010 emissions standards. There is a clear trend based on the past few years of experience that EURO VI can be met with SCR included in the final technology path.

\section{REDUCING AGENTS USED WITH THE SELECTIVE CATALYTIC REDUCTION TECHNOLOGY}

In order to optimize the SCR system application, investigation of other alternative reducing agents is required since ammonia is a toxic substance and presents serious problems of handling and storage. In general there is a need to find an alternative reducing agent to replace urea. From a technical standpoint this alternative reducing agent necessarily has to decompose into ammonia and do not produce products harmful to health under the conditions used in SCR systems. From a commercial standpoint the ideal reducing agent would be a non-toxic substance, easy to store, transport and handling with an affordable cost and available in abundance [2].

In SCR systems, ammonia could be used in two different forms: pure anhydrous ammonia and ammonia in aqueous solution. It has been studied the selective catalytic reduction of nitrogen oxides from exhaust gas using ammonia as a reducing agent obtained by the decomposition of guanidine, a product of protein metabolism, easily found in beet juice [24]. Guanidine salts came into the focus due to the fact of having a high nitrogen-content derivate of urea. Specially guanidinium formate has shown extraordinary solubility in water and therefore a possible high ammonia potential per liter solution compared to the classical $32.5 \%$ aqueous urea solution (AUS32) standardized in ISO 22241 and known as DEF, ARLA32 ${ }^{\circledR}$ or AdBlue $^{\circledR}$ [14]. Additionally a guanidine-based formulation could be observed with high freezing stability down to almost $-30^{\circ} \mathrm{C}$. The decomposition of this new precursor to ammonia $\mathrm{NH}_{3}$ could be done via a $\mathrm{TiO}_{2}$ catalyst completely without any critical side products at 
temperatures above $240^{\circ} \mathrm{C}$. The benefits observed by the researchers in this process are that $\mathrm{NH}_{3}$ is obtained very easily without the formation of undesirable products and can convert up to $90 \%$ of $\mathrm{NO}_{\mathrm{x}}$ emissions.

Another very usual ammonia precursor is urea. Urea $\left(\mathrm{H}_{2} \mathrm{~N} . \mathrm{CO} \cdot \mathrm{NH}_{2}\right)$ under normal conditions presents as a solid substance forming colorless prisms whose solubility in water at $17^{\circ} \mathrm{C}$ is $100 \mathrm{~g} / 100 \mathrm{~g} \mathrm{H}_{2} \mathrm{O}$. Normally the aqueous solutions of urea have solubility values in water of about $50 \%$ but for the SCR system a concentration of $32 \%$ mass-based is used [24]. At this concentration of $32 \%$ urea forms an eutectic solution characterized by a low crystallization point of $-11^{\circ} \mathrm{C}$. The use of eutectic solutions provides an additional advantage: the solid and liquid phases have the same concentration during the crystallization process. Even if there is a partial freeze in the tank of urea the crystallization will not change the concentration of urea solution that will feed the SCR system. In order to meet EURO VI one must search better ability to dramatically reduce $\mathrm{NO}_{\mathrm{x}}$. One of the ideas is to use urea based reducing agent and also using a pre-oxidation catalyst before the selective catalyst in a HDD vehicle [2]. They noted that the system consisting of a pre-oxidation catalyst allowed the system to reduce $\mathrm{NO}_{\mathrm{x}}$ emissions by an excellent level of $75 \%$ when compared to the level of only $45 \%$ efficiency using the same system without pre-oxidation catalyst. Another possible reducing agent is pure ammonium formate (CAS\#540-69-2), $\mathrm{HCOO} . \mathrm{NH}_{4}$ which is a solid substance with solubility in water at $0^{\circ} \mathrm{C}$ of $102 \mathrm{~g} / 100 \mathrm{~g} \mathrm{H}_{2} \mathrm{O}$ [2]. The compatibility between this kind of solutions and the materials used in SCR systems has not been fully proven yet. Therefore technological solutions using ammonium formate are so far impossible.

A fourth reducing agent, formamide starts its process of partial decomposition into carbon monoxide and ammonia at $180^{\circ} \mathrm{C}$. When heated abruptly breaks down into hydrogen cyanide (HCN) and steam. In the study of that generated the patent No. DE102005059250-A1, a mixture of water and formamide $\left(\mathrm{HCONH}_{2}\right)$ was used to reduce $\mathrm{NO}_{\mathrm{x}}$ from exhaust gases where the mixture used catalytically decomposed into $\mathrm{NH}_{3}$ [26]. They noted that the system under study fits perfectly to vehicle application because of frost resistance, storage stability of the mixture and for the absence of residues formation in the exhaust pipe. Formamide is a liquid easily miscible in water and can be used to produce aqueous mixtures with freezing points ranging from -25 to $-45^{\circ} \mathrm{C}$, well above the freezing point of aqueous eutectic mixture of urea that presents freezing point of $-11^{\circ} \mathrm{C}$ as described by [2]. Unlike urea he noted that the formamide is volatile, thermally stable up to $160^{\circ} \mathrm{C}$ and can be almost completely decomposed into $\mathrm{NH}_{3}$ and $\mathrm{CO}$ in selective catalysts and the carbon monoxide generated does not present a risk to the system.

Urea is the current reducing agent commercially and technically feasible. This study compared the urea-based solution with formamide-based solution in terms of their ability to reduce emissions level, mitigate ammonia slip issues and discussed the possibility to guarantee EURO VI emissions levels using this alternative reducing agent in SCR type ATS.

\section{EXPERIMENTAL APPARATUS}

The engine used in the present work is a 4 cylinder turbocharged diesel engine. The injection system is controlled by an electronic common rail system from $\mathrm{BOSCH}$ which allows multiple injections up to 1800 bar leading to better air/fuel mixture. It also has a SCR aftertreatment system installed. Tests were carried out at MWM Motores Diesel Tech Center 
in a test bench equipped with an electric dynamometer Schenck W-400. Table 1 presents engine characteristics.

Table 1: Engine characteristics.

\begin{tabular}{ll}
\hline Type & 4 Stroke SI \\
Number of cylinders & 4 in line \\
Aspiration & Turbocharged After-cooled \\
Cyl Head & Individual - 4 valves per cyl \\
Compression ratio & $16.8: 1$ \\
Firing Order & $1-4-3-2$ \\
Stroke (mm) & 137 \\
Bore (mm) & 105 \\
Cubic displacement (cc) & 4748 \\
Torque & 73.4 Kgf.m @ 1200-1600 rpm \\
Rated horsepower & $200 \mathrm{cv} \mathrm{@} \mathrm{2200} \mathrm{rpm}$ \\
Idle Speed & $800+/-100 \mathrm{rpm}$ \\
High Idle Speed & $2550+/-50 \mathrm{rpm}$ \\
ECU Control System & EDC7 UC31 \\
Oil Type & CH4 15W40 \\
Fuel Type & Brazilian S10 \\
\hline
\end{tabular}

Emissions measurements have been obtained via MEXA 7200 DEGR HORIBA Analyzer. The reducing agent injection system used in the tests was supplied by Bosch. This system has an integrated pump, filter, Pulse Width Modulation (PWM) valve to control the dosage of the reducing agent, an injector and an electronic control unit as shown in Figure 3. The input variables to control the dosage of the reducing agent are engine speed, torque and exhaust gas temperature before and after the catalyst.

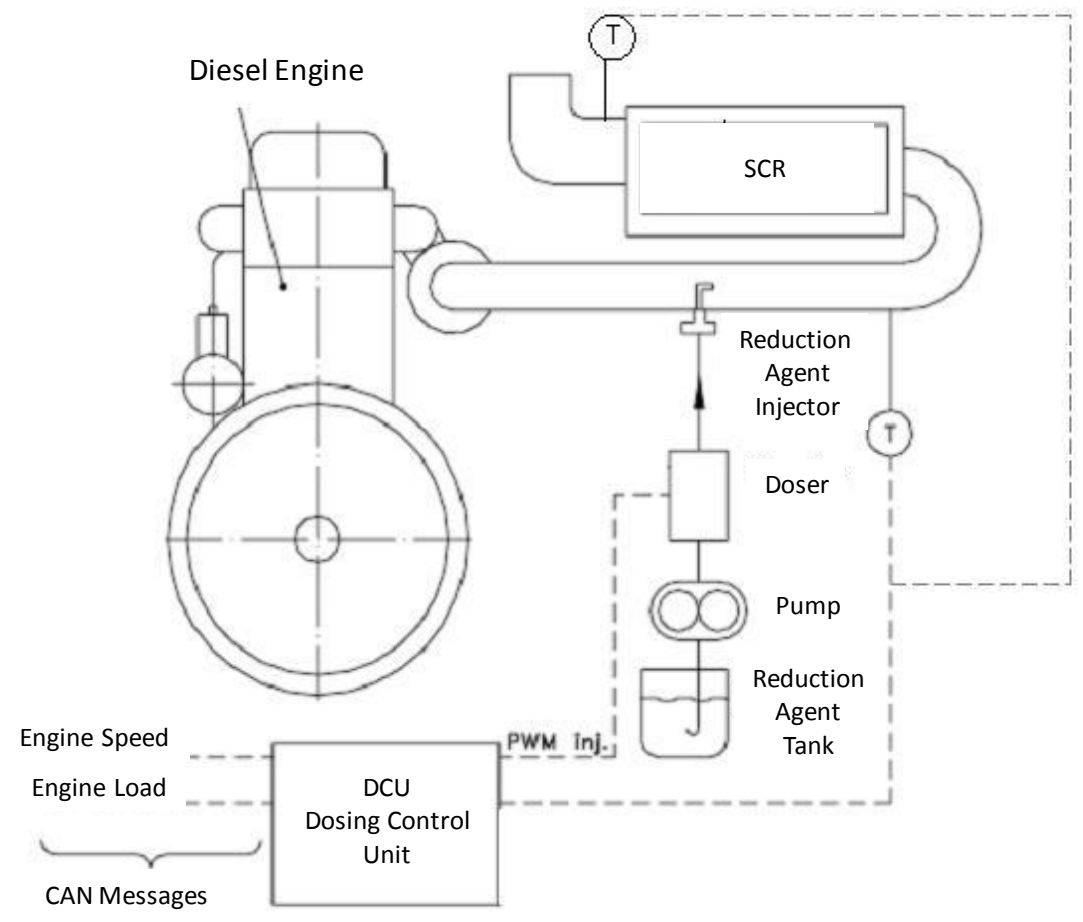

Figure 3: Engine and aftertreament system scheme applied on tests. 
During the development of SCR ATS besides the usual control and measurement of gases such as $\mathrm{CO}, \mathrm{CO}_{2}, \mathrm{HC}, \mathrm{NO}_{\mathrm{x}}$ and $\mathrm{O}_{2}$, the measurement of ammonia slip is extremely important as there is concern between the amount of $\mathrm{NO}_{\mathrm{x}}$ reduced and the amount of ammonia slip released to the atmosphere. The analyses of ammonia emissions have been done by using a SIEMENS analyzer with laser diode with measuring error of $+/-1 \%$, LDS6 control center, $7 \mathrm{MB} 6121$ model, LDS6 sensors and stainless steel piping heated to $200^{\circ} \mathrm{C}$.

The catalyst used for the selective catalytic reduction system consists of two extruded ceramic substrates with diameter of 10.5 inches and 5.0 inches in length obtained from a mixture of water-soluble compound derived from a selected metal and water. After drying the extruded substrate it was impregnated with vanadium and the ceramic used is a cordierite type [27].

In summary the evaluated reducing agents were:

- $\quad$ Adblue $^{\circledR}$ (mixture currently used in the automotive industry).

- $\quad$ Urea P.A. (aqueous mixture with $32 \%$ pure urea).

- $\quad$ Formamide P.A. (aqueous mixture with $35 \%$ pure formamide).

\section{METODOLOGY}

The ESC cycle for HDD engines was adopted since it represents relevant engine steady-state through the engine domain and is the base from EURO III to EURO V certification process. This cycle is operated through a sequence of 13 modes with different engine speed and load conditions [28]. The final result is a weighted average of the 13 modes as shown in Figure 4. By randomly selecting the rotation speed $B$, modes $8,4,3$ and 9 will be taken as reference since they have different values of torque then different values of exhaust gas temperatures which allow us to observe the effectiveness of each reducing agent on different temperature ranges. Usually exhaust gas temperature levels are very important to define catalyst material and design.

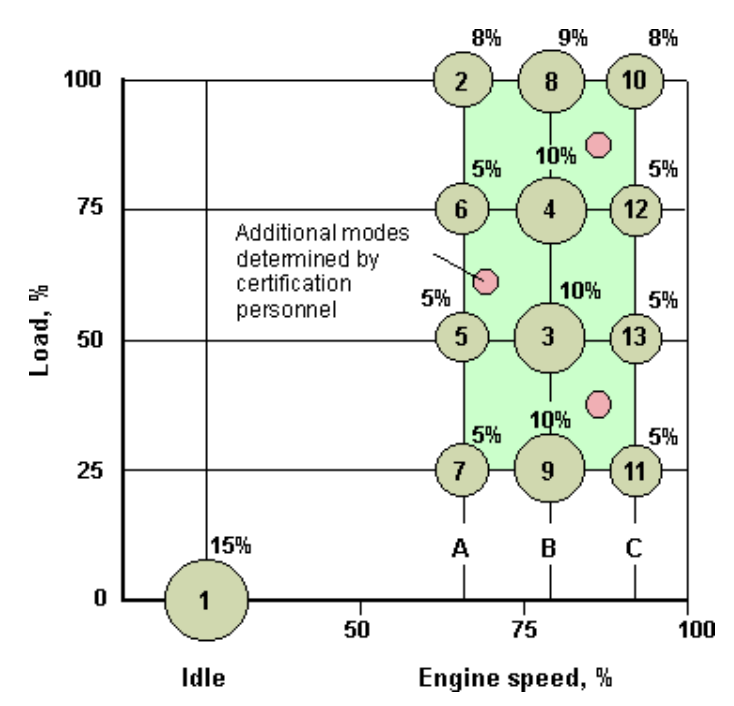

Figure 4: European steady state cycle.

On ESC cycle the engine is tested on an engine dynamometer over a sequence of steady-state modes reproduced in Table 2 [5]. It must be operated for the prescribed time in each mode, completing engine speed and load changes in the first 20 seconds. The specified speed shall be held within $\pm 50 \mathrm{rpm}$ and the specified torque shall be held within $\pm 2 \%$ of the maximum 
torque at the test speed. Emissions are measured during each mode and averaged over the cycle using a set of weighting factors.

Table 2: European steady state cycle.

\begin{tabular}{ccccc}
\hline Mode & Engine Speed & $\begin{array}{c}\text { Load } \\
(\%)\end{array}$ & $\begin{array}{c}\text { Weight Factor } \\
(\%)\end{array}$ & $\begin{array}{c}\text { Time } \\
(\text { min })\end{array}$ \\
\hline \hline 1 & Low idle & 0 & 15 & 4 \\
\hline 2 & A & 100 & 8 & 2 \\
3 & B & 50 & 10 & 2 \\
4 & B & 75 & 10 & 2 \\
5 & A & 50 & 5 & 2 \\
6 & A & 75 & 5 & 2 \\
\hline 7 & A & 25 & 5 & 2 \\
\hline 8 & B & 100 & 9 & 2 \\
9 & B & 25 & 10 & 2 \\
10 & C & 100 & 8 & 2 \\
11 & C & 25 & 5 & 2 \\
12 & C & 75 & 5 & 2 \\
\hline 13 & C & 50 & 5 & \\
\hline
\end{tabular}

$\mathrm{A}, \mathrm{B}$ and $\mathrm{C}$ speeds are determined based on engine lug curve and in the present case are $1372 \mathrm{rpm}, 1700 \mathrm{rpm}$ and $2032 \mathrm{rpm}$. Table 3 shows characteristics of the engine operating points observed in this work.

Table 3: Engine Characteristics.

\begin{tabular}{ccccc}
\hline $\begin{array}{c}\text { Mode } \\
(-)\end{array}$ & $\begin{array}{c}\text { Engine Speed } \\
(\text { rpm })\end{array}$ & $\begin{array}{c}\text { Load } \\
(\%)\end{array}$ & $\begin{array}{c}\text { Power } \\
(\mathrm{cv})\end{array}$ & $\begin{array}{c}\text { Torque } \\
(\text { Kgf.m })\end{array}$ \\
\hline \hline 3 & 1700 & 50 & 100 & 42 \\
4 & 1700 & 75 & 150 & 63 \\
8 & 1700 & 100 & 200 & 83 \\
9 & 1700 & 25 & 50 & 21 \\
\hline
\end{tabular}

Initially for all modes under study measurements of $\mathrm{CO}, \mathrm{CO}_{2}, \mathrm{HC}, \mathrm{NO}_{\mathrm{x}}$ and $\mathrm{O}_{2}$ without using any compound to reduce $\mathrm{NO}_{\mathrm{x}}$ have been done and these measurements were considered as references for the other evaluations defining a baseline. For each ESC mode under study reducing agent flow rate values, Q_reducing agent, were fixed and calculated from Equation 5 using theoretical efficiency values named Alpha defined in Equation 6. Thus the percentages of the reducing agents in the solutions have been chosen as to keep constant the theoretical final amount of ammonia injected into the exhaust system upstream catalyst.

$$
Q_{\text {reducingagent }}=1,476 \frac{N O x_{p r e ́ c a t}(\mathrm{ppm}) \text { Power }(\mathrm{cv})}{\text { Alpha }}
$$




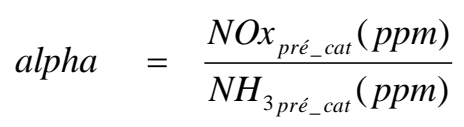

With the engine always stabilized in the condition of $1700 \mathrm{rpm}$ and constant torque for each mode under study after reaching the water temperature and lubricating oil above $85^{\circ} \mathrm{C}$ and $100^{\circ} \mathrm{C}$, respectively, through the dosing system, predetermined amounts of reducing agent were injected into the exhaust system upstream catalyst during 3 minutes. The amounts dosed for each mode based on alpha values can be found in Table 4. For each mode and different reducing agent via data acquisition system based on engine speed, engine load and reducing agent flow rate values of $\mathrm{NO}_{\mathrm{x}}$ tailpipe, ammonia, $\mathrm{CO}_{2}, \mathrm{CO}, \mathrm{O}_{2}$ and $\mathrm{HC}$ have been collected.

In order to avoid possible variations that could cause relevant changes in the combustion process jeopardizing the findings and the analysis conclusion, some parameters were freezed during the evaluation process for each different operating modes (in the present case, modes 8, 4, 3 and 9): diesel temperature $\left(40^{\circ} \mathrm{C}\right)$ and water temperature $\left(80^{\circ} \mathrm{C}\right)$ were kept constant and lube oil temperature was only monitored. Other parameters that have direct influence on the behavior of the combustion process were also controlled during the tests. Some of them are: air inlet temperature and pressure, temperature and pressure at the inlet manifold (outlet CAC) and temperature and pressure upstream and downstream turbocharger.

Table 4: Reducing Agent Flow Rate.

\begin{tabular}{ccccc}
\hline \multicolumn{5}{c}{ Reduction Agent Flow Rate $(\mathrm{g} / \mathrm{h})$} \\
alpha & Mode 9 & Mode 3 & Mode 4 & Mode 8 \\
\hline \hline 1.2 & 805.7 & 1492.9 & 2095.5 & 2794.0 \\
1.1 & 738.5 & 1368.5 & 1920.9 & 2561.2 \\
1.0 & 671.4 & 1244.1 & 1746.3 & 2328.4 \\
0.9 & 604.3 & 1119.7 & 1571.6 & 2095.5 \\
0.8 & 537.1 & 995.3 & 1397.0 & 1862.7 \\
0.7 & 470.0 & 870.9 & 1222.4 & 1629.8 \\
0.6 & 402.8 & 746.5 & 1047.8 & 1397.0 \\
0.5 & 335.7 & 622.1 & 873.1 & 1164.2 \\
0.4 & 268.6 & 497.6 & 698.5 & 931.3 \\
0.3 & 201.4 & 373.2 & 523.9 & 698.5 \\
0.2 & 134.3 & 248.8 & 349.3 & 465.7 \\
0.1 & 67.1 & 124.4 & 174.6 & 232.8 \\
\hline
\end{tabular}

The intake air manifold temperature was controlled via test bench control system and automation where $33^{\circ} \mathrm{C}$ was set for testing different modes and the maximum deviation observed was approximately $+/-1^{\circ} \mathrm{C}$ what did not cause changes in the combustion process and consequently in the gaseous emissions. The other temperatures showed excellent repeatability during all tests conducted with different reducing agents. Pressure values also showed excellent repeatability in all tests conducted with different reducing agents although not directly controlled by the control and automation system available at the test bench. In addition to the boundary conditions previously mentioned, other parameters of major importance to the combustion process have been also strictly controlled to ensure that changes in the results obtained from the exhaust gases emission were only and solely a result of using 
different types of reducing agent. Among the combustion parameters we could mention the most important ones such as start of the main injection (SOI), main injection quantity, start of pilot-injection, pilot-injection quantity and fuel injection pressure (also known as Fuel Unit Pressure (FUP)).

Table 5 shows the combustion parameters settings used during the different reducing agents study. Another parameter of equal importance for our analyses or the selective catalytic reduction system is the exhaust flow rate. Being the exhaust flow rate the sum of the fuel flow rate plus the inlet air flow rate according to the mass conservation law. The variation to this magnitude for the tests conducted with different reducing agents is not over $3 \%$ where the average values are also shown in the last line of Table 5.

Table 5: Combustion parameters setting and exhaust flow.

\begin{tabular}{lcccc}
\hline \multicolumn{1}{c}{ Parameter } & \multicolumn{4}{c}{ ESC Mode } \\
& 9 & 3 & 4 & 8 \\
\hline \hline Start of main injection ( ${ }^{\circ}$ BTDC) & -2 & -2 & -2 & 6 \\
Main injection quantity (mg/stk) & 50 & 75 & 100 & 150 \\
Start of pre-injection (dif) & 8 & 12 & 8 & 8 \\
Pre-injection quantity (mg/stk) & 1.5 & 9 & 10.5 & 1.5 \\
Injection Pressure (bar) & 1600 & 1600 & 1650 & 1800 \\
Exhaust flow (kg/h) & 350 & 450 & 525 & 550 \\
\hline
\end{tabular}

In addition to the boundary conditions and combustion parameters already mentioned two other magnitudes also important for the analysis are the inlet and outlet temperatures of exhaust gases in the SCR catalyst observed during the tests. Since the efficiency of the selective reduction system is directly proportional to the exhaust gas temperature in the catalyst, Table 6 presents the average temperature values of the exhaust gases in the exhaust manifold, in the exhaust pipe after turbine as well as the inlet and outlet temperatures of gases in the catalyst observed on the various tests conducted with the two types of studied reducing agents.

Table 6: Average temperatures.

\begin{tabular}{ccccc}
\hline Mode & $\begin{array}{c}\text { Exhaust. } \\
\text { Manifold } \\
\left({ }^{\circ} \mathrm{C}\right)\end{array}$ & $\begin{array}{c}\text { Outlet } \\
\text { Turbine } \\
\left({ }^{\circ} \mathrm{C}\right)\end{array}$ & $\begin{array}{c}\text { T SCR inlet } \\
\left({ }^{\circ} \mathrm{C}\right)\end{array}$ & $\begin{array}{c}\text { T SCR outlet } \\
\left({ }^{\circ} \mathrm{C}\right)\end{array}$ \\
\hline \hline 9 & 362 & 286 & 272 & 267 \\
3 & 485 & 373 & 377 & 369 \\
4 & 610 & 459 & 459 & 442 \\
8 & 728 & 563 & 562 & 547 \\
\hline
\end{tabular}




\section{RESULTS AND DISCUSSIONS}

There are several parameters which affect the selective catalytic reduction aftertreatment system such as temperature, $\mathrm{NO}, \mathrm{NH}_{3}$ initial concentration and oxygen among others.

It is important to emphasize that the basis for the straight comparison has been made assuming the same converted $\mathrm{NH}_{3}$ upstream catalyst which means the urea and formamide dosing were calculated accordingly. Therefore for the same alpha both compounds have exactly the same amount of $\mathrm{NH}_{3}$.

Table 7 shows the $\mathrm{O}_{2}$ concentration from different reducing agents on ESC modes 9, 3, 4 and 8. The oxygen amount involved in the SCR systems plays an important role on the $\mathrm{NO}_{\mathrm{x}}$ reduction efficiency.

Table 7: Oxygen ranges observed on ESC modes 9, 3, 4 and 8.

\begin{tabular}{ccccc}
\hline \multirow{2}{*}{ Parameter to same $\alpha=$ cte } & 9 & 3 & 4 & 8 \\
\hline \hline O $_{2}$ Range $(\%)$ & $14.2-14.8$ & $11.5-12.2$ & $8.8-9.4$ & $5.2-6.2$ \\
AdBlue ${ }^{\circledR}$ & 0.78 & 0.83 & 0.81 & 0.50 \\
Urea P.A. & 0.79 & 0.83 & 0.81 & 0.58 \\
Formamide P.A. & 0.74 & 0.78 & 0.69 & 0.46 \\
T_SCR_inlet $\left({ }^{\circ} \mathrm{C}\right)$ & 276 & 371 & 451 & 566 \\
\hline
\end{tabular}

Considering only the $\mathrm{O}_{2}$ ranges observed during the experiments one can observe that when the $\mathrm{O}_{2}$ present in the reaction increases the concentration of reducing agent required to achieve the maximum efficiency is lower. Between $9-12 \%$ of $\mathrm{O}_{2}$ it is possible to achieve up to $99 \%$ of efficiency, maximum conversion achieved. But if $\mathrm{O}_{2}$ continue to increase the maximum efficiency achieved reduces to $95 \%$ probably consequence of relative lower temperature $\left(276^{\circ} \mathrm{C}\right)$. It is not possible to achieve more than $65 \%$ of efficiency when lower $\mathrm{O}_{2}$ concentration and higher temperature $\left(566^{\circ} \mathrm{C}\right)$ are considered. These results agree partially with works conducted previously [28].

\section{1. $\mathrm{NO}_{\mathrm{x}}$ and Ammonia Slip Emissions Evaluation}

Modes 3, 4 and 9 are the evaluated modes from ESC with lower temperature and similar behavior has been observed when it comes to $\mathrm{NO}_{\mathrm{x}}$ reduction and ammonia slip. Therefore results from Mode 4 will be considered as a representative one among Modes 3, 4 and 9.

Figure 5 presents a comparison between the efficiencies obtained with AdBlue ${ }^{\circledR}$ and Urea P.A. evaluated in ESC mode 4. The results for $\mathrm{NO}_{\mathrm{x}}$ emissions show that those two agents have similar behavior, which was expected since both have the same urea content. 


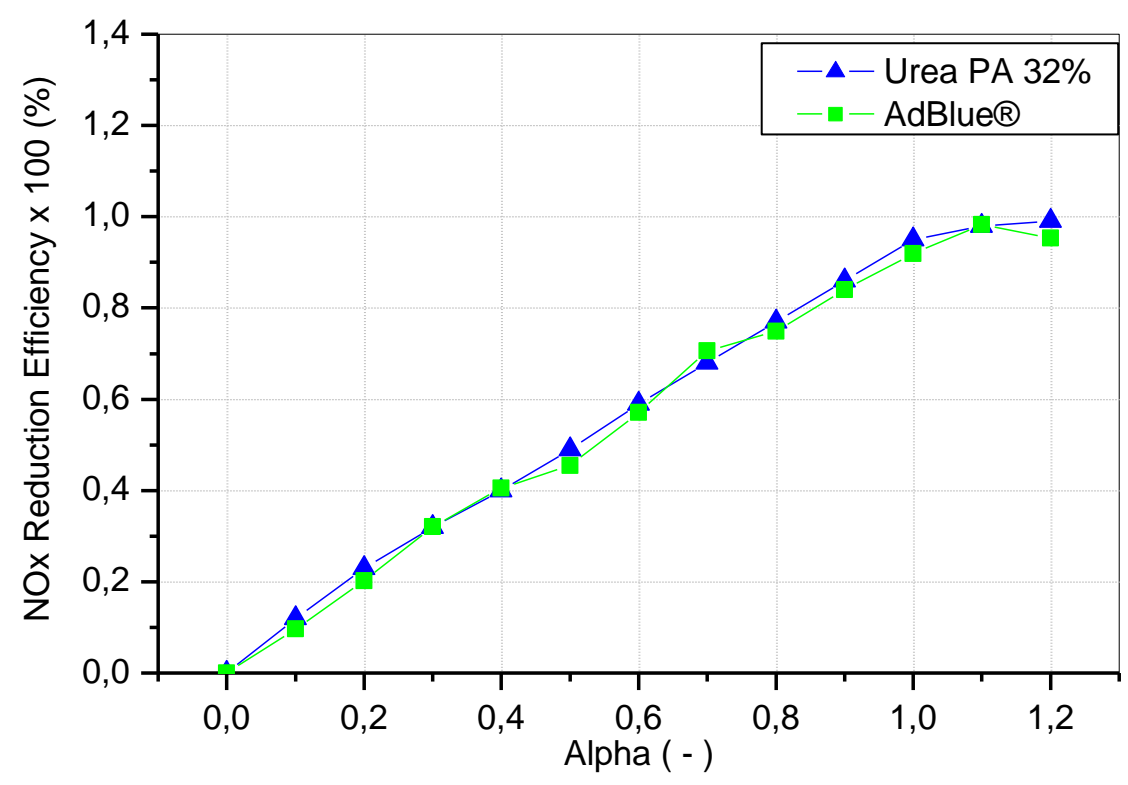

Figure 5: Urea P.A and AdBlue ${ }^{\circledR} \mathrm{NO}_{\mathrm{x}}$ reduction efficiency comparison.

Based on that similarity from now on the AdBlue ${ }^{\circledR}$ results will not be part of the comparisons and only urea P.A. and formamide P.A. will be presented.

From the experiments held with modes 9,3 and 4 it was noted that for Formamide P.A there was a reduction in the efficiency of $\mathrm{NO}_{\mathrm{x}}$ reduction as compared to urea P.A. compound as shown on Figure 6. For the same alpha there is a difference of $10 \%$ between them. This means that for achieving the same efficiency range would be necessary to add $10 \%$ formamide in composition.

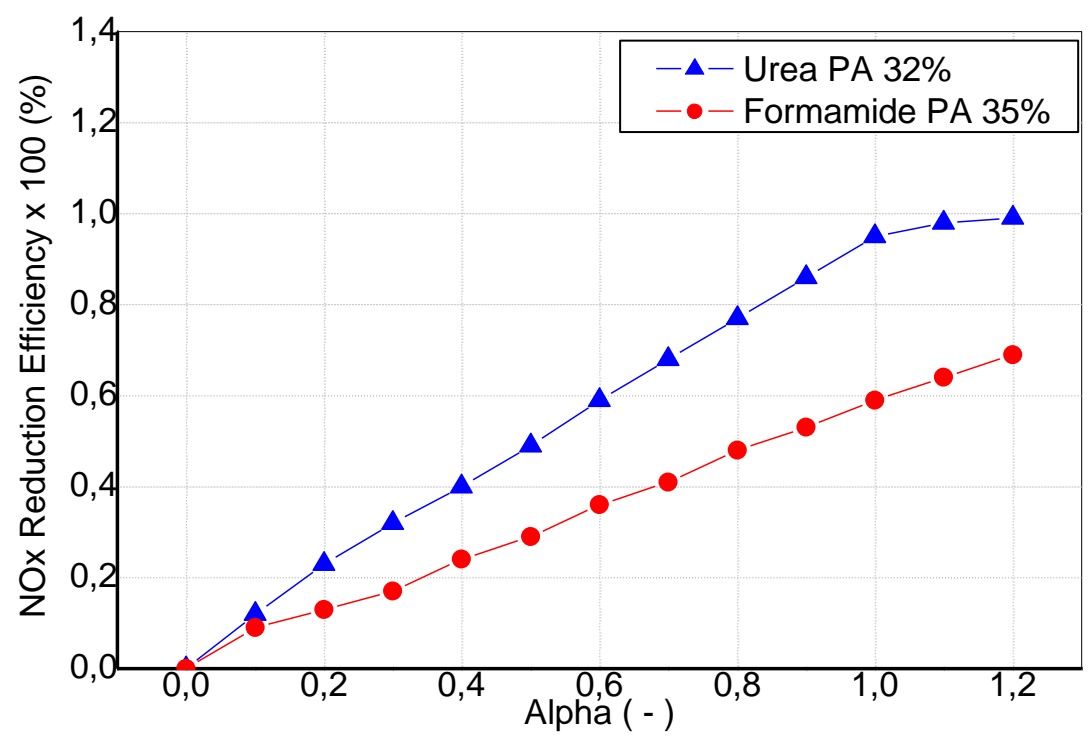

Figure 6: $\mathrm{NO}_{\mathrm{x}}$ reduction efficiency on ESC mode 4. 
On the other hand when the exhaust temperature increases as in Mode 8 formamide intensely loses its efficiency. However at temperatures above $460^{\circ} \mathrm{C}$ the conversion efficiency of $\mathrm{NO}_{\mathrm{x}}$ for all reducing agents features a significant reduction when compared to the efficiency shown by the same agents in modes with lower temperatures as modes 9 , 3 and 4 which operate in the temperature range from 270 to $450^{\circ} \mathrm{C}$ as can be seeing in Figure 7.

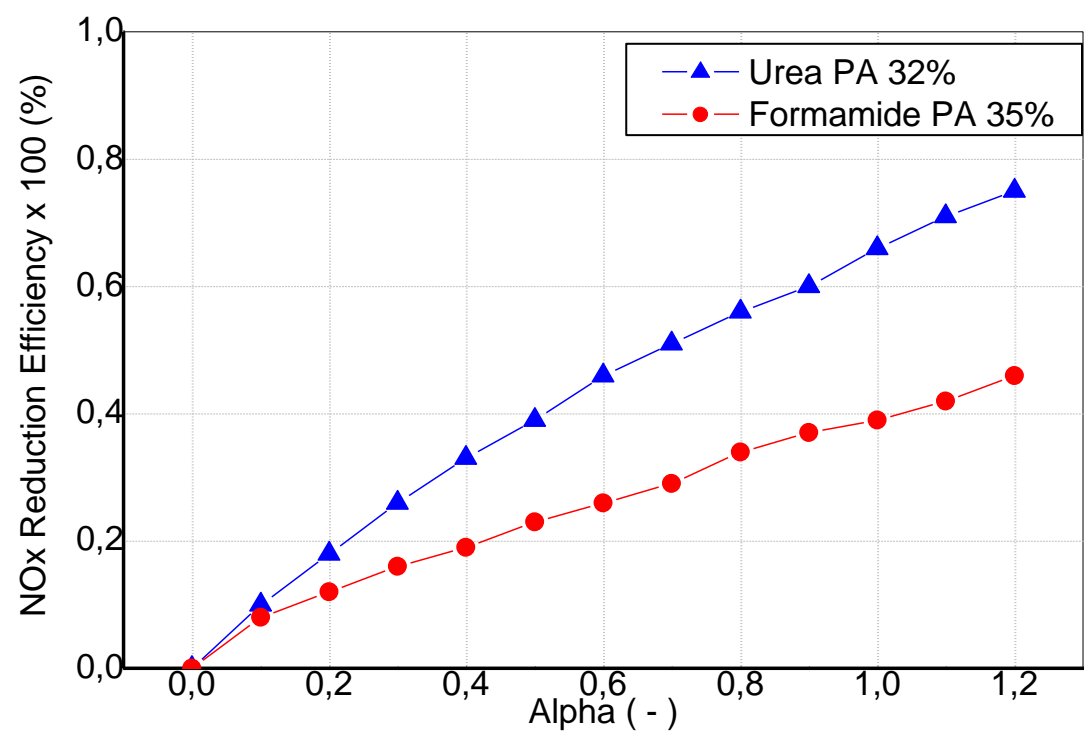

Figure 7: $\mathrm{NO}_{\mathrm{x}}$ reduction efficiency on ESC mode 8.

As mentioned before the evaluation of the reduction system must also observe the behavior of ammonia slip as during the selective catalytic reduction process not always all ammonia converted is used to neutralize $\mathrm{NO}_{\mathrm{x}}$ as it mainly depends on the concentration of this pollutant, exhaust flow rate, type of agent and exhaust gas temperature.

As for ammonia slip it is noted that for low temperature modes 9, 3 and 4 when the NO concentration becomes low or close to the complete cancellation of $\mathrm{NO}_{\mathrm{x}}$ an exponential increase in the ammonia slip begins. Figure 8 shows the result for Mode 4 illustrating that behavior. For those modes the formamide P.A. compound did not show ammonia slip but on the other hand the annulment of $\mathrm{NO}_{\mathrm{x}}$ did not happen up to the agent flow rate here investigated. 


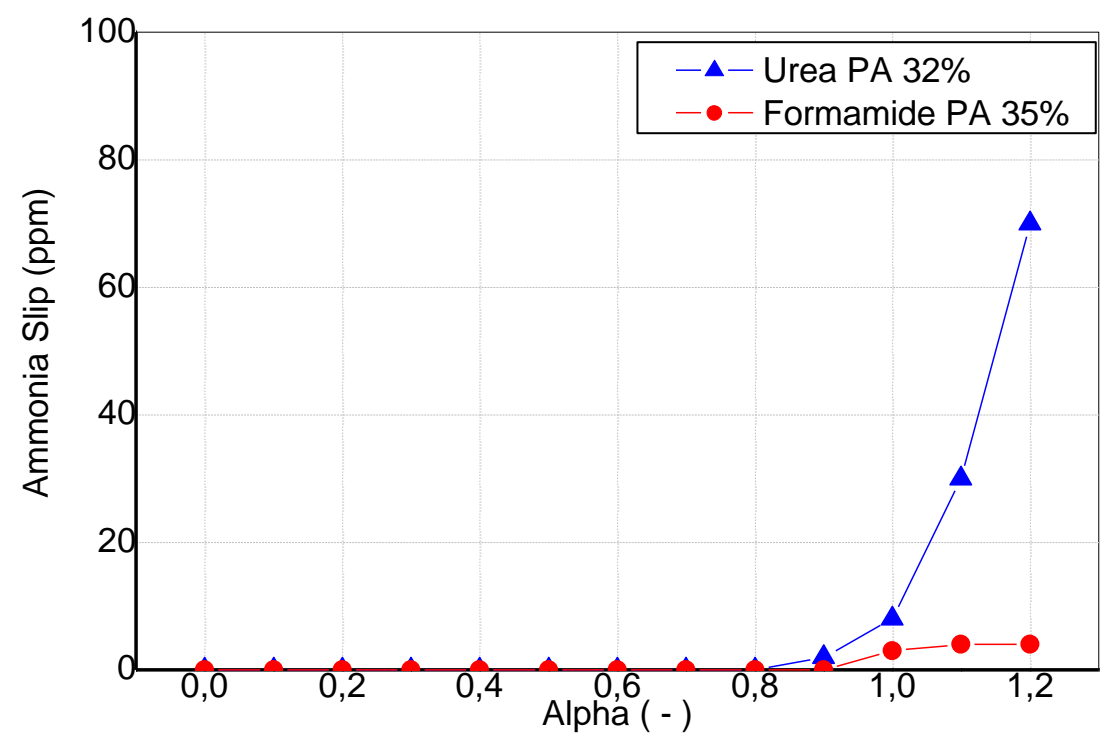

Figure 8: Ammonia slip values from Mode 4.

Moreover for conditions with higher temperature as Mode 8 shown in Figure 9 there is generally a drop in efficiency of agents leading to slight ammonia slip even in a situation close to the annulment of $\mathrm{NO}_{\mathrm{x}}$ emissions as happened in lower temperature modes.

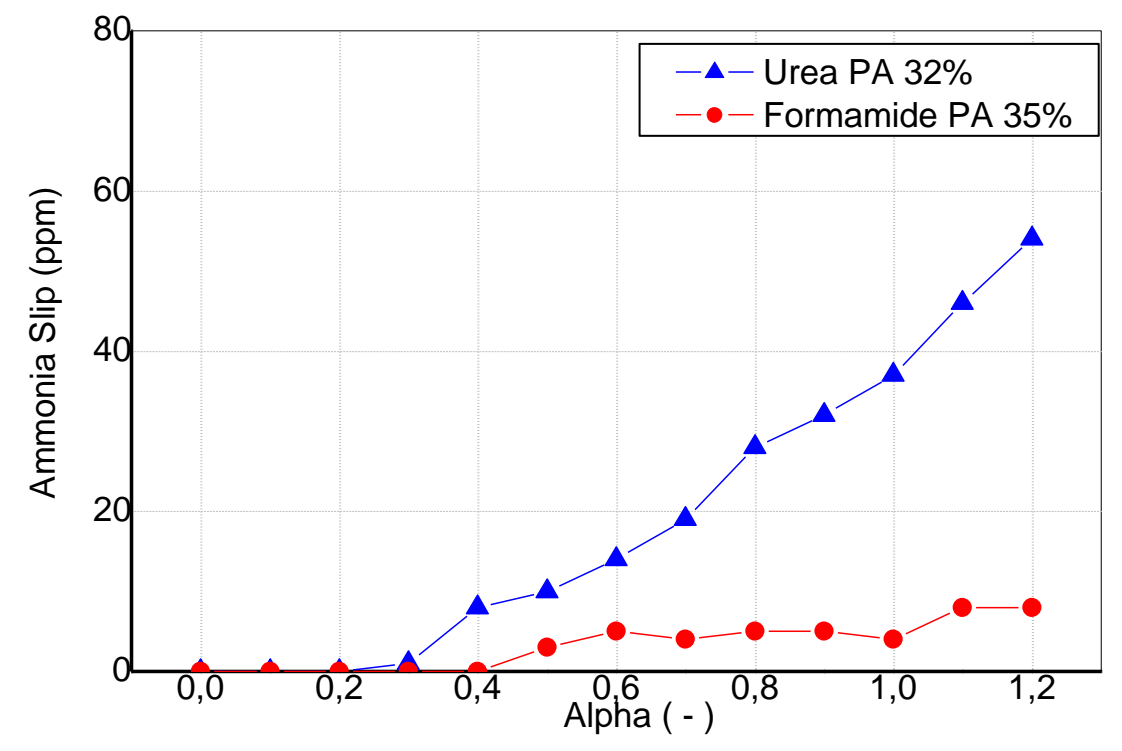

Figure 9: Ammonia slip values from Mode 8.

Considering the EURO V ammonia slip limits most vehicles which today use SCR Only as ATS does not have slip catalyst applied along the SCR catalyst. Depending on the chosen strategy for a more stringent EURO VI limits the slip catalyst will be mandatory. In this case a greater ATS configuration is expected, since the ammonia slip catalyst is usually installed downstream SCR catalyst. 


\subsection{CO Emissions Evaluation}

Modes 3, 4 and 9 are the evaluated modes from ESC with lower temperature and similar behavior has been observed when it comes to $\mathrm{CO}$ reduction. Therefore results from Mode 4 will be considered as a representative one among Modes 3, 4 and 9.

Regarding the CO emissions two different behaviors have been observed during our experiments. The first one with urea P.A. compound which showed virtually no increase in this gas emissions where the chemical reactions that occurred in the process of $\mathrm{NO}_{\mathrm{x}}$ reduction reactions followed the desirable reactions and resulted in a reduction of $\mathrm{NO}_{\mathrm{x}}$ to $\mathrm{N}_{2}$. The second behavior has been observed with formamide P.A. compound where there was an important increase in $\mathrm{CO}$ emissions. Figure 10 shows the representative behavior from Mode 8.

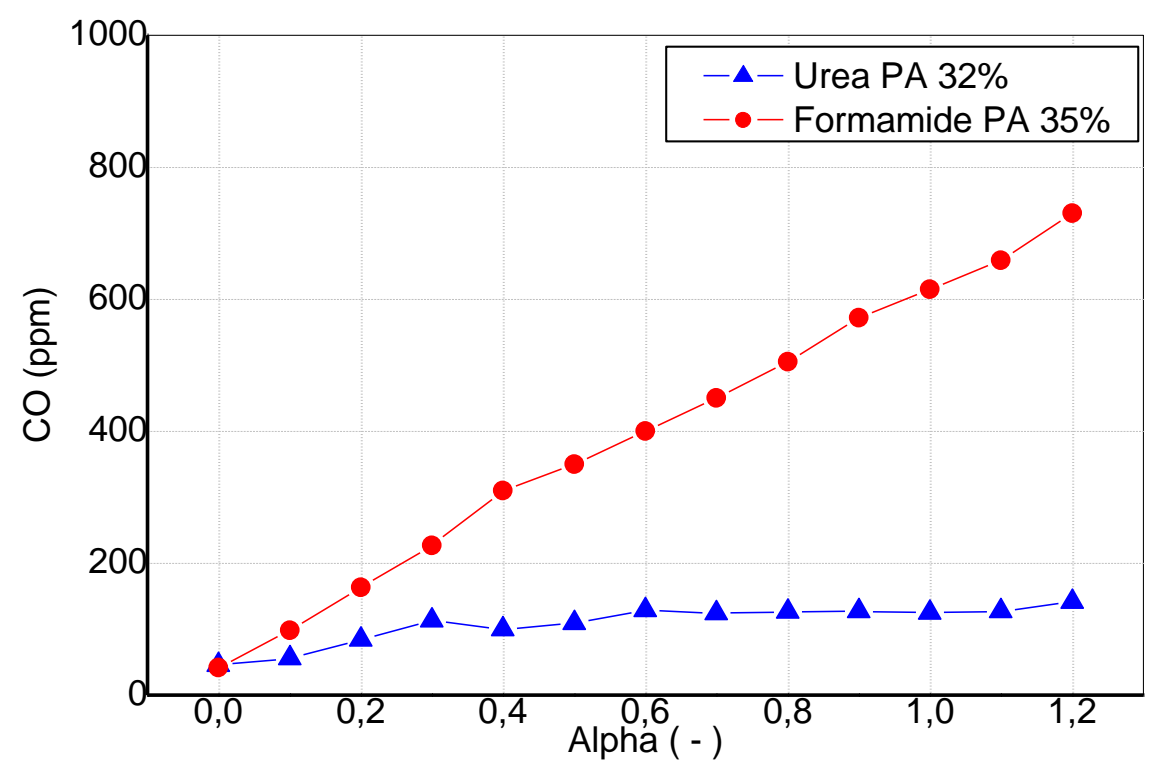

Figure 10: Carbon monoxide emissions from Mode 8.

Modes with lower exhaust temperature as Modes 9, 3 and 4 presented pretty much the same behavior result from Mode 8 as shown on Figure 11.

The literature shows that formamide starts its process of partial decomposition into carbon monoxide and ammonia at $180^{\circ} \mathrm{C}$. The formamide decomposition occurs via competition between two mechanisms:

$$
\begin{aligned}
& \mathrm{NH}_{2} \mathrm{CHO} \rightarrow \mathrm{NH}_{3}+\mathrm{CO} \\
& \mathrm{NH}_{2} \mathrm{CHO} \rightarrow \mathrm{H}_{2}+\mathrm{HNCO}
\end{aligned}
$$

The context of the present work does not deal with the study of kinetics and reaction mechanisms but it can be inferred, based on [2], in accordance with experimental data that there was predominance of the de-carbonation mechanism as compared to hydrogenation as there was an increase in temperature, which agrees to literature [29]. The inlet temperatures in 
the SCR shown are equal to $272,377,459$ and $562{ }^{\circ} \mathrm{C}$ in ESC modes 9, 3, 4 and 8 respectively.

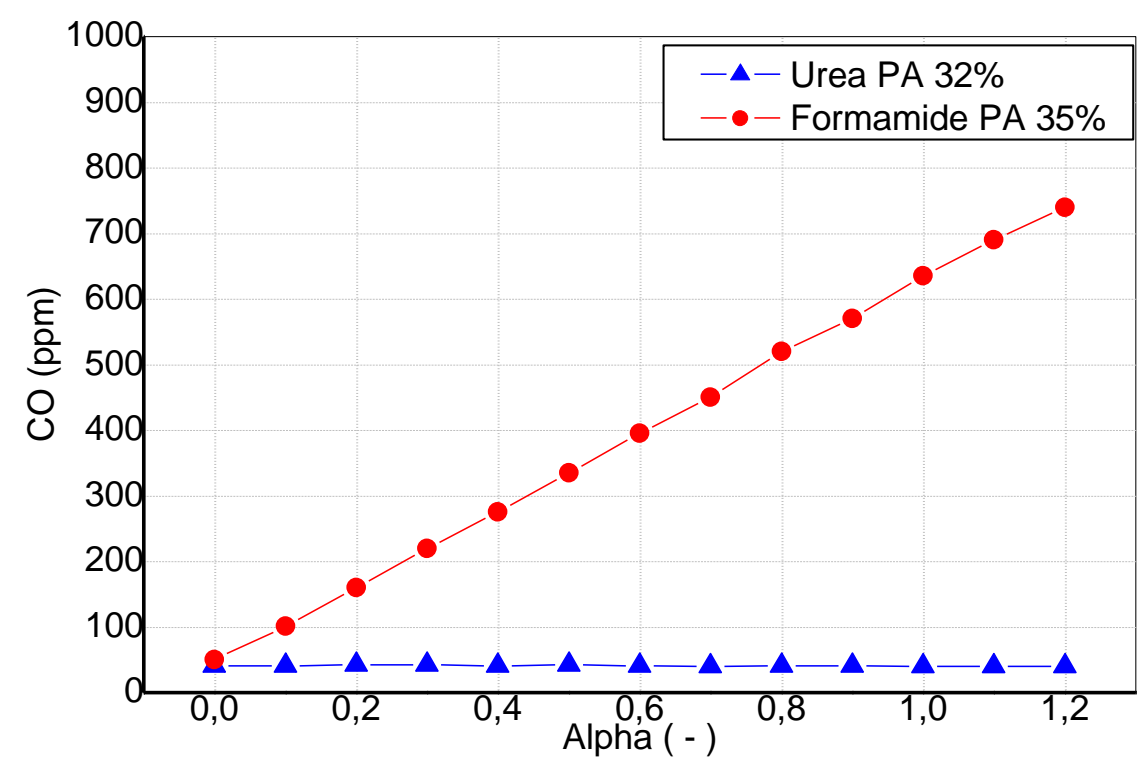

Figure 11: Carbon monoxide emissions from Mode 4.

\subsection{HC Emissions Evaluation}

When it comes to $\mathrm{HC}$ emissions a similar behavior comparing to $\mathrm{CO}$ results have been observed. Formamide P.A. compound presented a significant increase on HC emissions on all evaluated modes $8,4,3$ and 9 while the emissions of that gas with urea-based mixtures remained virtually unchanged as shown on Figures 12 and 13 from Modes 4 and 8. Considering the results obtained using Formamide P.A. on different ESC Modes the trend to have a $\mathrm{HC}$ emissions increase on modes with higher exhaust temperatures can be observed.

Currently in the literature there are few records of the real reasons that would cause a significant increase in $\mathrm{HC}$ emissions by catalytic reduction systems. However it is known that the presence of $\mathrm{HC}$ in these systems may be responsible for the low efficiency in the reduction of $\mathrm{NO}_{\mathrm{x}}$. 


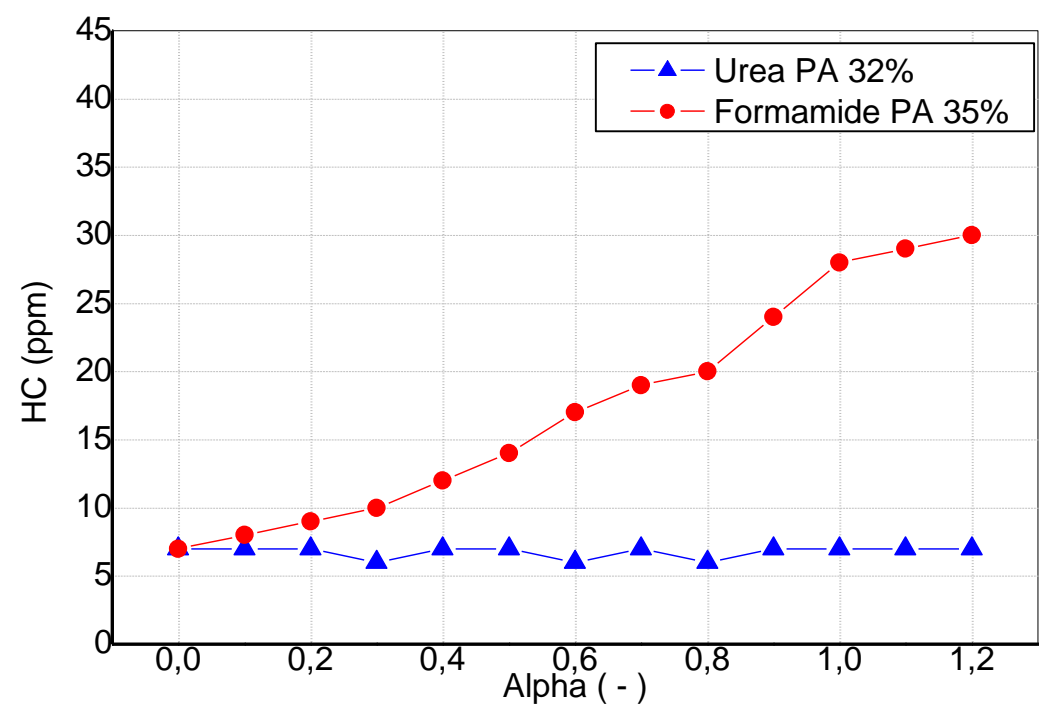

Figure 12: Carbon monoxide emissions from Mode 4.

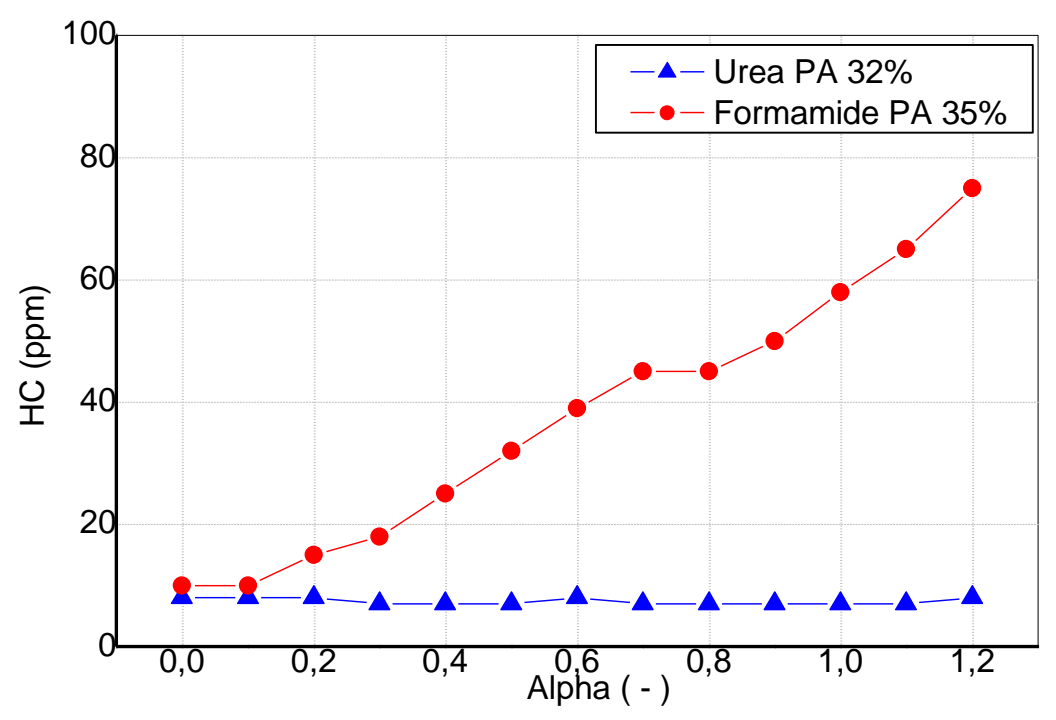

Figure 13: Carbon monoxide emissions from Mode 8.

\section{COMMENTS AND CONCLUSIONS}

SCR is the preferred solution for meeting future $\mathrm{NO}_{\mathrm{x}}$ stringent legislation limits for HDD applications. Challenges are achieving maximum $\mathrm{NO}_{\mathrm{x}}$ conversion with a minimum level of ammonia slip, enhanced low-temperature performance of SCR converters and satisfying inuse compliance requirements.

As proposed this study examined the behavior of two different reducing agents applied to the SCR system. Regarding the efficiency of the SCR catalyst system as to $\mathrm{NO}_{\mathrm{x}}$ reduction the mixtures containing urea as a base were the most efficient ones but on the other hand also the 
ones presenting the highest values of ammonia slip what requires manufacturers of diesel engines to use a slip catalyst with the SCR system in order to control the ammonia slip values to approximately $25 \mathrm{ppm}$ on ESC and ETC cycles from EURO V and even lower values of $10 \mathrm{ppm}$ on the World Harmonized Cycles (WHSC and WHTC) for EURO VI. The formamide-based mixtures do not present efficiency as significant as the urea-based mixtures but the ammonia levels produced by those mixtures are virtually zero.

Regarding $\mathrm{CO}$ and $\mathrm{HC}$ emissions formamide-based mixtures showed a significant increase in the emission of these two gases what might explain the efficiency loss in the reduction of $\mathrm{NO}_{\mathrm{x}}$, while in urea-based mixtures values remained virtually unchanged.

Nowadays urea-based mixtures are the most widely used reducing agent in selective catalytic systems but the use of formamide-based mixtures despite being less efficient, about $20 \%$ lower than those urea-based mixtures, have shown an interesting alternative to reduce $\mathrm{NO}_{\mathrm{x}}$.

Considering the extremely low $\mathrm{NO}_{\mathrm{x}}$ tailpipe emissions limits of $0.4 \mathrm{~g} / \mathrm{kW}$.h required on EURO VI for HDD applications Diesel engine manufacturers have several technology paths to keep $\mathrm{NO}_{\mathrm{x}}$ within the legislation limits.

Among the available technology paths Figure 14 shows the most important strategies which include not only high-technology ATS but also in-cylinder emissions control strategies capable to reduce $\mathrm{NO}_{\mathrm{x}}$ to values lower than the legislations limits requirements and close to its complete annulment.

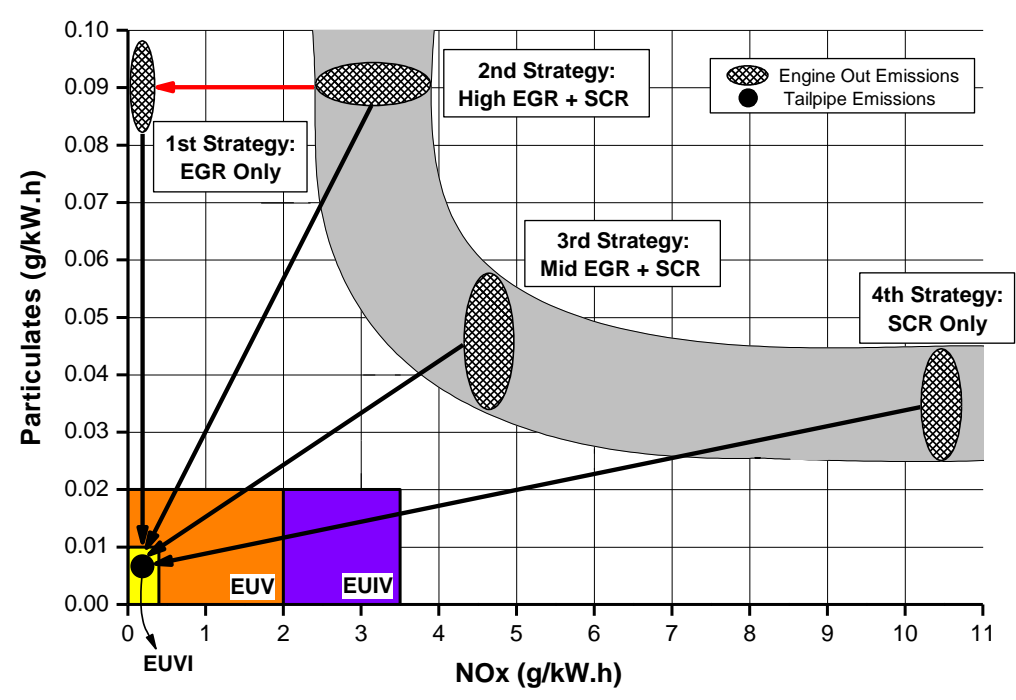

Figure 14: EURO VI emissions roadmap.

The first strategy EGR only requires massive EGR rates from 40 to $45 \%$ on the full load and also partial load areas to keep the $\mathrm{NO}_{\mathrm{x}}$ within the legislations limits as no ATS to further control $\mathrm{NO}_{\mathrm{x}}$ is applied. Such high EGR rates can lead to misfire and drivability issues. It also presents extremely high heat rejection and might cause EGR cooler fouling issues among others [30]. 
Extremely high EGR rates definitely can reduce $\mathrm{NO}_{\mathrm{x}}$ to the legislation limits but an exponential increase in PM is expected. High PM levels are usually controlled either via incylinder control by applying high injection pressures (FUP) from $2000-2500$ bar and high boost pressures via dual stage turbocharger systems or later in the exhaust system by applying a DOC + DPF system. The EGR Only strategy can be considered a viable solution from the technical stand point but that strategy should be carefully developed to avoid serious issues on the field.

The second strategy High EGR + SCR combines in-cylinder emissions control via EGR and a SCR ATS to control $\mathrm{NO}_{\mathrm{x}}$. That strategy still requires high EGR rates from 30 to $40 \%$ and $\mathrm{NO}_{\mathrm{x}}$ engine out values from 2.5 to $4 \mathrm{~g} / \mathrm{kW}$.h. Moderate heat rejection due to EGR is expected but misfire and drivability issues are not likely to happen. With relative low $\mathrm{NO}_{\mathrm{x}}$ engine-out levels a low efficiency and low cost SCR system is an option as its $\mathrm{NO}_{\mathrm{x}}$ reduction required efficiency will not be higher than 70 to $75 \%$. Low urea consumption from this strategy is expected. By reducing the EGR rates when compared to the first strategy EGR Only PM engine-out will be lower as well but still a high pressure injection system would be required along with DOC + DPF ATS. The idea of using formamide-based reducing agents starts to be feasible from the technical stand point considering the low ATS $\mathrm{NO}_{\mathrm{x}}$ reduction requirements from this second strategy. As mentioned before formamide-based compounds presents lower efficiency when compared to urea-based compounds but on the other hand ammonia slip levels are virtually zero what can allow the slip cat to be removed from the ATS leading then to a reasonably reduction cost.

The third strategy Mid EGR + SCR also combines in-cylinder control via EGR and SCR ATS to control $\mathrm{NO}_{\mathrm{x}}$ but the EGR rates ranges from 20 to $30 \%$ and $\mathrm{NO}_{\mathrm{x}}$ engine-out values from 4 to $5 \mathrm{~g} / \mathrm{kW}$.h. Low heat rejection is expected and a SCR ATS with higher efficiency from $80-$ $85 \%$ is required. As EGR rates are relatively low PM engine-out results are also low and a regular injection system with pressure levels up to 1800 bar can be applied but still a DOC + DPF ATS is required to control PM tailpipe values. That strategy is the preferred solution from most OEMs in Europe and United States nowadays. Although that strategy requires a relatively high efficiency ATS formamide-based reducing agents are an option to replace the regular urea-based compound and again the slip cat can be removed from the ATS reducing its final cost.

The last but not least strategy the SCR Only is for sure the most challenging strategy among the ones described before. Higher $\mathrm{NO}_{\mathrm{x}}$ engine-out can be applied from 10 to $12 \mathrm{~g} / \mathrm{kW}$.h leading to an outstanding BSFC result but for sure an extremely high efficiency ATS is required to reduce $\mathrm{NO}_{\mathrm{x}}$ to levels below $0.4 \mathrm{~g} / \mathrm{kW}$.h so efficiencies higher than 90 to $95 \%$ are mandatory. Such high efficiencies might lead to high urea consumption, crystallization issues and definitely requires a slip cat to control the ammonia slip and keep it within the required 10 ppm from EURO VI standards. Different from the last two strategies where formamide-based compound can be an alternative due to its high required $\mathrm{NO}_{\mathrm{x}}$ reduction efficiency, formamidebase compounds are not an option on the SCR Only strategy.

As a suggestion for future work other compounds like Diesel and ethanol might be an excellent object of study to complement the current one. Moreover further evaluations on the transient cycles (ETC or WHTC) using more realistic conditions than only a few steady state modes are a good option. Although formamide can be used with success replacing the urea- 
based compounds one important concern is about the formaldehyde concentration release to environment. Thus formaldehyde emissions evaluation is required.

\section{DEFINITIONS AND ABBREVIATIONS}

$\begin{array}{ll}\text { ATS: } & \text { Aftertreatment System } \\ \text { BSFC: } & \text { Brake Specific Fuel Consumption } \\ \text { CAC: } & \text { Charge Air Cooler } \\ \text { CARB: } & \text { California Air Resources Board } \\ \text { CFD: } & \text { Computational Fluid Dynamics } \\ \text { CO: } & \text { Oxide of Carbon } \\ \text { CO }_{2}: & \text { Dioxide of Carbon } \\ \text { DEF: } & \text { Diesel Exhaust Fluid } \\ \text { DOC: } & \text { Diesel Oxidation Catalyst } \\ \text { DPF: } & \text { Diesel Particulate Filter } \\ \text { EBT: } & \text { Exhaust Back Temperature } \\ \text { EGR: } & \text { Exhaust Gas Recirculation } \\ \text { EPA: } & \text { Environmental Protection Agency } \\ \text { ESC: } & \text { European Stationary Cycle } \\ \text { ETC: } & \text { European Transient Cycle } \\ \text { FUP: } & \text { Fuel Unit Pressure } \\ \text { HC: } & \text { Hydrocarbon } \\ \text { HDD: } & \text { Heavy Duty Diesel } \\ \text { HSD: } & \text { High Speed Diesel } \\ \text { JMLIT: } & \text { Japanese Ministry of Land, Infrastructure and Transportation } \\ \text { MDD: } & \text { Medium Duty Diesel } \\ \text { NO }: & \text { Oxides of Nitrogen } \\ \text { OEMs: } & \text { Original Equipment Manufacturer } \\ \text { PM: } & \text { Particulate Matter } \\ \text { PWM: } & \text { Pulse Width Modulation } \\ \text { SCR: } & \text { Selective Catalytic Reduction } \\ \text { SOI: } & \text { Start of Main Injection } \\ \text { VCA: } & \text { Vehicle Certification Agency } \\ \text { WHSC: } & \text { World Harmonized Stationary Cycle } \\ \text { WHTC: } & \text { World Harmonized Transient Cycle }\end{array}$

\section{REFERENCES}

[1].ARGACHOY, C. \& PIMENTA, O. P., Phenomenological model of particulate matter emission from direct injection diesel engines, Journal of the Brazilian Society of Mechanical Science and Engineering, v. XXVII, n. 3, p. 266-273, ABCM, 2005.

[2].LOURENCO, A. A. M., MARTINS, C.A., LACAVA, P. T. \& FERREIRA, M. A., Selective catalytic reduction study with alternative reducing agents, Environmental Engineering Science, v. 30 Issue 5, p. 221-231. doi:10.1089/ees.2012.0008, 2012. 
[3].PARVUleSCU V.I., GRANGE P., DELMON B., Catalytic Removal of NO, Catalysis Today 46, p. 233- 316, 1998.

[4].WILLAND J., Selective non-catalytic $\mathrm{NO}_{\mathbf{x}}$ reduction in Diesel engines using aqueous urea, SAE Technical Paper Series 982651, 1998.

[5].Emission test cycles description, available at http://www.dieselnet.com/standards searched on May, $20^{\text {th }} 2015$.

[6].COBB, D., GLATCH, L., RUUD, J. and SNYDER, S., Application of selective catalytic reduction (SCR) technology for $\mathrm{NO}_{\mathrm{x}}$ reduction from refinery combustion sources, Environmental Progress and Sustainable Energy, Vol. 10, pp. 49-59, doi 10.1002/ep.670100116, 2006.

[7]. METKAR, P. S., HAROLD, M. P. \& BALAKOTAIAH, V., Experimental and kinetic modeling study of $\mathrm{NH}-\mathrm{SCR}$ of $\mathrm{NO}_{x}$ on $\mathrm{Fe}-\mathrm{ZSM}-5, \mathrm{Cu}$-chabazite and combined $\mathrm{Fe}-$ and $\mathrm{Cu}$-zeolite monolithic catalysts, Chemical engineering science 87, pp. 51-66, Science Direct Elsevier, Elsevier Ltd, 0009-2509, 2013.

[8].BAUMGARTEN, C., Mixture formation in internal combustion engines, SpringerVerlag Heidelberg, Hannover, Germany, 2005.

[9].ARROWSMITH, D., BOTT, A., \& BUSH, P., Development of a compact ureaSCR+CRT'M system for heavy-duty Diesel using a Design of Experiments approach, SAE Technical Paper Series, 2006-01-0636, 2006.

[10]. BIRKHOLD, F., MEINGAST, U., WASSERMAN, P. \& DEUTSCHMAN, O., Modeling and simulation of the injection of urea-water-solution for automotive SCR DeNO $_{x}$ systems, 0926-3373, Applied Catalysis B: Environmental, 70, pp. 119-127, Science Direct Elsevier, doi:10.1016/j.apcatb.2005.12.035, 2007.

[11]. LINDSTEDT, R.P., LOCKWOOD, F.C. \& SELIM M.A., A detailed kinetic study of ammonia oxidation, Combustion Science and Technology, Vol. 108, n. 4-6, pp. 231-254, 1995.

[12]. NOVA I., NOVA I.,, CIARDELlI C., TRONCONI T., CHATTERJEE D. \& WEIBEL M., $\mathbf{N H}_{3}-\mathrm{NO} / \mathrm{NO}_{2}$ SCR for Diesel exhausts after treatment: mechanism and modeling of a catalytic converter, Topics in Catalysis Vol. 42-43, 2007.

[13]. CIARDELli, C., NOVA, I., TRONCONI, E., CHATTERJEE, D., BURKHARDT, D. \& WEIBEL, M., SCR-DeNO ${ }_{x}$ for diesel engine exhaust aftertreatment: unsteady-state kinetic study and monolith reactor modeling, Chemical Engineering Science, 70 (1-4), 80, 2004.

[14]. Robert BOSCH, SCR Systems Controls, Catalogue, 2010.

[15]. GRANGer P. \& PARVUlescu V.I., Past and Present in DENO Catalysis, Elsevier, First Edition 2007.

[16]. WILLI R., RODUIT B., KOEPPEL R., WOKAUN A. \& BAIKER A., Selective reduction of $\mathrm{NO}$ by $\mathrm{NH}_{3}$ over vanadia-based commercial catalyst: parametric sensitivity and kinetic modeling, Chemical Engineering Science, 51 (11), pp. 2897-2902, 1996.

[17]. BRANDENBERGER S., CASAPU M., KRÖCHER O., TISSLER A. \& ALTHOFF R., Hydrothermal deactivation of Fe-ZSM-5 catalysts for the selective catalytic reduction of $\mathbf{N O}$ with $\mathbf{N H}_{3}$, Applied Catalyst, Vol. 101, pp. 649-659, 2011.

[18]. BISWAS S., VERMA V., SCHAUER J. J. \& SIOUTAS C., Chemical speciation of PM emissions from heavy-duty diesel vehicles equipped with diesel particulate filter (DPF) and selective catalytic reduction (SCR) retrofits, Atmospheric Environment, 43: 1917-1925, 2009.

[19]. HERNER J.D., Hu S., ROBERTSON W.H., HUAI T., CHANG M.C.O., RIEGER P. \& Ayala A., Effect of advanced aftertreatment for PM and $\mathbf{N O}_{\mathbf{x}}$ 
reduction on heavy-duty Diesel engine ultrafine particle emissions, Environmental Science Technology, 45: 2413-2419, 2011.

[20]. KÜNKEL, C., ODENBRAND, C., \& WESTERBERG, B., A catalytic NO aftertreatment system for heavy-duty trucks using diesel fuel as reducing agent, SAE Technical Paper 1999-01-3563, 1999, doi:10.4271/1999-01-3563, 1999.

[21]. GERHART, C., KRIMMER, H., HAMMER, B., SCHULZ, B., KRÖCHER, O., PEITZ, D., SATTELMAYER, T., TOSHEV, P., WACHTMEISTER, G., HEUBUCH, A., \& JACOB, E., Development of a $3^{\text {rd }}$ generation SCR $\mathbf{N H}_{3}$-direct dosing system for highly efficient DENO $_{\mathbf{x}}$, SAE International Journal of Engines, 2012-01-1078,Vol. 5 N. 3 pp. 938-946, doi: 10.4271/2012-01-1078, 2012.

[22]. WALKER A.P. BLAKEMAN, P.G., ILKENHANS T., MAGNUSSON B. \& McDONALD A.C., The development and in-field demonstration of highly durable SCR catalyst system, SAE Technical Paper Series 2004-01-1289, 2004.

[23]. WILLEMS F. \& CLOUDT R., Experimental demonstration of a new model-based SCR control strategy for cleaner heavy-duty diesel engines, IEEE Transactions on Control Systems Technology, Vol. 19, doi 10.1109/TCST.2010.2057510, 2011.

[24]. BASF Catalogue, AdBlue, Technical Leaflet, M 6621 e, pp 1-6, 2006.

[25]. GIESHOFF, J., SCHÄFER-SINDLINGER, A., SPURK, P., van den TILLAART, J. et al., Improved SCR systems for heavy duty applications, SAE Technical Paper 2000-01-0189, 2000, doi:10.4271/2000-01-0189, 2000.

[26]. JACOB et al. (1990), Ammonia precursor substance and method for the selective catalytic reduction of nitrogen oxides in oxygen-containing exhaust gases of vehicles, Patent DE 102005059250 B4, 1990.

[27]. JOHNSON MATTHEY PLC, The Catalyst Technical Handbook, 2005.

[28]. DJERAD S., CROCOLL M., KURETI S., TIFOUTI L. \& WEISWEILER W., Effect of oxygen concentration on the $\mathrm{NO}_{\mathrm{x}}$ reduction with ammonia over $\mathrm{V}_{\mathbf{2}} \mathrm{O}_{5}$ $\mathbf{W O}_{3} / \mathbf{T i O}_{\mathbf{2}}$ catalyst, Catalysis Today 113, pp. 208-214, 2006.

[29]. MARTELL, J. M., YU, H.T. \& GODDARD, J.D., Molecular decompositions of acetaldehyde and formamide: theoretical studies using Hartree-Fock, MollerPlesset and density functional theories, Molecular Physics, Vol. 92, 497-502, 1997.

[30]. ALMEIDA, F. L., ZOLDAK, P., WANG ,Y., SOBIESIAK, A. \& LACAVA, P. T., Multi-dimensional engine modeling study of EGR, fuel pressure, postinjection and compression ratio for a light duty diesel engine, ASME ICEF Technical Conference, ICEF2014-5661, pp. V002T06A017; 14 pages doi:10.1115/ICEF2014-5661; ISBN: 978-0-7918-4617-9, 2014. 